Jurnal Administrasi Negara

ISSN : 2598-4039 (Online)

ISSN : 2302-2221 (Print)
Eny Diana Mudrikah, Roy V. Salomo

Program Magister Ilmu Administrasi

Fakultas Ilmu Administrasi

Universitas Indonesia

\title{
STAKEHOLDER ENGAGEMENT DALAM PERANCANGAN INDIKATOR KINERJA PENGAWASAN OBAT
}

\author{
Eny Diana Mudrikah, Roy V. Salomo \\ Program Magister Ilmu Administrasi, Fakultas Ilmu Administrasi \\ Universitas Indonesia \\ Corresponding Author, email: eny.diana@ui.ac.id
}

\begin{abstract}
Performance indicators play an important role in the government accountability system as well as policy formulation in areas such as planning, resource allocation, and also good governance. The findings of assessment of the drug surveillance system performance indicators surfacing in the period 2015-2019 are perceived to be less sensitive in presenting performance, regarding that accomplishing these targets endures a significant challenge. Stakeholder engagement can significantly improve governance by either increasing trust in the government and social cohesion. The purpose of this research is to explore the role of stakeholders in designing performance indicators in the field of drug control. Through a constructivist research paradigm as well as a qualitative instrumentation method approach, trailed by triangulation-based analysis of various inputs, these are discovered the citizen engagement typology in establishing drug control performance indicators is at third level, which is a form of more intense engagement between government institutions and citizens as stakeholders, in which each entity has a role in the determination and affects over the decisions. Instead with stakeholder engagement, at least certain positive outcomes have been obtained, such as promoting the actualization of both the principles of transparency and accountability, as well as empowering worldviews and explanations on performance indicators which have been formulated, so that they might be of excellent volume as well as the citizen seems to be more ready to favor the performance of government institutions.
\end{abstract}

Keywords: Drug, Engagement, Performance Indikator, Stakeholders

\begin{abstract}
Abstrak
Indikator kinerja memegang peranan penting dalam sistem akuntabilitas pemerintah serta pengambilan kebijakan terkait perencanaan, alokasi sumber daya, serta tata kelola yang lebih baik. Hasil review terhadap indikator kinerja sistem pengawasan obat beredar pada periode 2015-2019 dinilai kurang sensitif menggambarkan kinerja mengingat tantangan untuk mencapai target tersebut masih cukup banyak. Dalam upaya peningkatan tata kelola pemerintahan, keterlibatan pemangku kepentingan dapat membangun kepercayaan kepada pemerintah serta membangun kohesi sosial. Penelitian berikut berupaya mengeksplorasi peran pemangku kepentingan dalam perancangan indikator kinerja pembangunan di bidang pengawasan obat. Melalui paradigma penelitian konstruktivis dengan pendekatan metode perolehan data secara kualitatif dilanjutkan analisis berbasis triangulasi dari berbagai sumber informasi diperoleh kesimpulan bahwa tipologi keterlibatan dalam penetapan indikator kinerja pengawasan obat telah berada pada level 3 (tiga) yaitu participation in public decision making, yang merupakan bentuk keterlibatan lebih intens antara organisasi publik dan warga sebagai pemangku kepentingan dimana masing-masing pihak memiliki peran dan pengaruh atas indikator kinerja yang ditetapkan. Melalui keterlibatan pemangku kepentingan, setidaknya diperoleh beberapa dampak positif yaitu antara lain mendukung terwujudnya prinsip transparansi dan akuntabilitas, serta memperkaya perspektif dan argumentasi atas indikator kinerja yang disusun sehingga menjadikannya lebih berkualitas dan kinerja lembaga pemerintah lebih berpeluang diterima masyarakat.
\end{abstract}

Kata Kunci: Indikator Kinerja, Keterlibatan, Obat, Pemangku Kepentingan 
Jurnal Administrasi Negara

ISSN : 2598-4039 (Online)

ISSN : 2302-2221 (Print)
Eny Diana Mudrikah, Roy V. Salomo

Program Magister Ilmu Administrasi

Fakultas Ilmu Administrasi

Universitas Indonesia

\section{PENDAHULUAN}

Pengawasan obat dan makanan merupakan salah satu agenda reformasi pembangunan nasional bidang kesehatan sebagai upaya untuk meningkatkan kualitas hidup manusia Indonesia sehingga mendukung percepatan pencapaian tujuan pembangunan nasional. Sistem pengawasan tersebut juga bersifat strategis dan prioritas karena tidak hanya mendukung aspek kesehatan tetapi juga ketahanan bangsa. Peredaran obat yang berkualitas buruk tidak hanya berdampak pada kesehatan tetapi juga bidang ekonomi maupun sosial ekonomi. Selain memperkuat tata kelola farmasi, hal prioritas lain terkait upaya pencegahan adalah dengan memasukkan pengukurannya dalam target pembangunan berkelanjutan untuk memastikan kualitas dan keamanan obat beredar (Nayyar. et al, 2019).

Saat ini, keterlibatan warga sebagai pemangku kepentingan dalam tata kelola pemerintahan semakin ditekankan. Warga negara diharapkan semakin terlibat aktif dalam proses perancangan kebijakan serta regulasi masyarakat. Tentunya hal tersebut harus disertai dengan pertimbangan menyeluruh terkait kualifikasi dan kompetensi (Matsuda, 2009). Keterlibatan pemangku kepentingan (stakeholder engagement) merupakan instrumen bermakna dalam meningkatkan kepercayaan kepada pemerintah karena dua alasan. Pertama, perencana pemerintah dan pengelola program dapat memperoleh data yang benar dan akurat tentang prioritas dan preferensi yang sangat diinginkan oleh para pemangku kepentingan. Kedua, keterlibatan tersebut dapat memberikan umpan balik penting bagi para pengelola program dalam upaya meningkatkan kredibilitas laporan pemerintah terhadap sistem yang sedang berlangsung (Halachmi \& Holzer, 2010).

Perbedaan antara konsep warga (citizen) dan pengguna layanan publik (customer) sebagaimana dinyatakan oleh Pollit \& Bouckaert (1995) dalam Bovaird \& Loeffler (2016) yaitu dimana warga negara dapat didefinisikan sebagai konsentrasi hak dan kewajiban dalam pribadi seorang individu dalam negara konstitusional, di bawah supremasi hukum, dan dalam hierarki hukum dan peraturan. Sementara pengguna layanan publik berfokus pada kepuasan kebutuhan individu, dalam situasi pasar penawaran dan permintaan barang dan jasa pada suatu hierarki kebutuhan, serta tunduk pada kesediaan untuk membayar. Warga negara adalah bagian dari kontrak sosial, sedangkan pengguna layanan publik adalah bagian dari kontrak pasar. Dalam praktiknya, citizen seringkali merupakan perwakilan dari warga negara sebagai pemangku kepentingan yang turut terlibat dalam kaitannya dengan aspek representatif melalui penunjukan oleh otoritas publik, 
Jurnal Administrasi Negara

ISSN : 2598-4039 (Online)

ISSN : 2302-2221 (Print)
Eny Diana Mudrikah, Roy V. Salomo

Program Magister Ilmu Administrasi

Fakultas Ilmu Administrasi

Universitas Indonesia seleksi acak, ataupun metode pemilihan lainnya (Hunter, et al, 2016).

Indikator kinerja pembangunan dibidang pengawasan obat sebagaimana telah tertuang dalam Rencana Pembangunan Jangka Menengah (RPJMN) periode 2010-2014 adalah "Proporsi Obat yang memenuhi standar (aman, manfaat, dan mutu)", yang selanjutnya pada periode 2015-2019 formulasi kalimatnya disesuaikan menjadi "Persentase Obat memenuhi syarat" dimana implementasinya dilaksanakan oleh lembaga pemerintah yang memiliki kewenangan dan tanggung jawab dalam bidang pengawasan obat dan makanan yaitu Badan Pengawas Obat dan Makanan $(\mathrm{BPOM})$, dengan target dan realisasi ditunjukkan dalam tabel 1 berikut.

Tabel 1. Perbandingan Target dan Capaian Indikator Kinerja

"Persentase Obat Memenuhi Syarat" pada periode tahun 2010 - 2019

\begin{tabular}{lllllll}
\hline RPJMN & \multicolumn{3}{c}{ RPJMN 2010-2014 } & \multicolumn{3}{c}{ RPJMN 2015-2019 } \\
Tahun & Target & Realisasi & \multicolumn{2}{c}{ Capaian } & Target & \multicolumn{2}{l}{ Realisasi Capaian } \\
Tahun I & 94.0 & 94.2 & 100.2 & 92.0 & 98.6 & 107.2 \\
Tahun II & 94.4 & 99.0 & 104.8 & 92.5 & 98.8 & 106.8 \\
Tahun III & 94.8 & 99.4 & 104.8 & 93.0 & 99.2 & 106.7 \\
Tahun IV & 95.2 & 99.4 & 104.4 & 93.5 & 98.2 & 105.0 \\
Tahun V & 95.6 & 99.2 & 103.7 & 94.0 & 97.7 & 104.0 \\
\hline
\end{tabular}

Sumber: Laporan Kinerja BPOM (diolah), 2021

Tabel 1 di atas menunjukkan bahwa capaian indikator pembangunan di bidang pengawasan obat pada periode tahun 2010-2019 senantiasa melebihi $100 \%$. Data tersebut juga mengindikasikan bahwa rata-rata selama 10 tahun terakhir, sebanyak $98 \%$ obat yang beredar di masyarakat secara luas telah memenuhi persyaratan mutu, keamanan, khasiat, serta manfaatnya. Namun demikian, pencapaian yang cenderung tinggi tersebut menjadi catatan tersendiri bagi Kementerian Perencanaan Pembangunan Nasional
(PPN)/Bappenas pada saat pelaksanaan Evaluasi Paruh Waktu RPJMN 2015-2019 yaitu bahwa tantangan masih cukup banyak, sehingga diperlukan penajaman metode dalam pengukuran capaian untuk menggambarkan kondisi lapangan yang lebih akurat. Hal ini dikaitkan dengan masih maraknya berbagai pemberitaan terkait peredaran obat tidak memenuhi standar di Indonesia.

Selain itu, tren capaian dari tahun ke tahun juga dinilai kurang sensitif untuk menggambarkan progres kinerja 
Jurnal Administrasi Negara

ISSN : 2598-4039 (Online)

ISSN : 2302-2221 (Print)
Eny Diana Mudrikah, Roy V. Salomo

Program Magister Ilmu Administrasi

Fakultas Ilmu Administrasi

Universitas Indonesia
(Bappenas, 2019). Bappenas memberikan masukan bahwa "ke depan indikator pengawasan obat dan makanan 20202024 perlu dijabarkan menjadi indikator yang mampu memberikan gambaran sejauh mana upaya pengawasan obat dan makanan mampu memberikan dampak perlindungan kesehatan masyarakat dan mencakup pengukuran hasil pengawasan untuk seluruh komoditas dan prosesnya". Beberapa hal yang dapat dilakukan antara lain adalah melalui pemetaan indikator serupa yang mampu mengukur dampak terhadap upaya pengawasan serta keterbukaan sistem pengawasan obat melalui keterlibatan berbagai pihak yang diregulasi. Hal ini selaras juga dengan Peraturan Menteri Negara Pendayagunaan Aparatur Negara Nomor PER/09/M.PAN/5/2007 tentang Pedoman Umum Penetapan Indikator Kinerja Utama di lingkungan Instansi Pemerintah pasal 7 yang menyebutkan bahwa "Pemilihan dan penetapan indikator kinerja utama di lingkungan instansi pemerintah melibatkan pemangku kepentingan (stakeholders) dari instansi pemerintah yang bersangkutan".

Pada sektor publik, indikator kinerja semestinya dapat membantu pengguna laporan dalam memahami input, output, outcome, dan kebijakan pada suatu periode tertentu. Indikator yang tidak mencerminkan kinerja secara akurat dapat berimbas pada citra kinerja suatu negara (Dooren, Caluwe, \& Lonti,
2012). Merujuk pada dokumen Rancangan Teknokratik Rencana Pembangunan Jangka Menengah Nasional 2020-2024, "Persentase Obat Memenuhi Syarat" masih menjadi indikator kinerja pembangunan dibidang pengawasan obat dengan definisi operasional "Obat" yang telah diperluas sehingga perhitungan angka capaiannya mencakup Obat Tradisional, Suplemen Kesehatan, dan Kosmetik, dimana hal tersebut berbeda dengan definisi konseptual obat sebagaimana dalam UU 36 Tahun 2009 tentang Kesehatan. Selain itu, target awal yang ditetapkan pada tahun 2020 adalah sebesar 80,8\%, cukup jauh berbeda dengan tren sebelumnya. Dalam hal ini, belum diketahui sejauh mana peran keterlibatan pemangku kepentingan (stakeholders) dalam perancangan indikator kinerja tersebut.

Parmenter (2020) mendefinisikan Indikator Kinerja Utama (IKU) sebagai indikator-indikator yang berfokus pada aspek kinerja organisasi serta memiliki peranan penting bagi keberhasilan suatu organisasi saat ini maupun masa depan. 7 karakteristik dari IKU yang dikemukakan Parmenter yaitu 1) Nonfinansial, 2) Diukur secara berkala, 3) Fokus utama dari aktifitas organisasi, 4) Sederhana dan mudah dipahami, 5) Berbasis tim, 6) berdampak signifikan bagi keberhasilan organisasi, 7) Hampir tidak memiliki konsekuensi negatif. Ketika diatur dalam konteks strategis dan dikembangkan menurut kriteria 
Jurnal Administrasi Negara

ISSN : 2598-4039 (Online)

ISSN : 2302-2221 (Print)
Eny Diana Mudrikah, Roy V. Salomo

Program Magister Ilmu Administrasi

Fakultas Ilmu Administrasi

Universitas Indonesia tertentu, indikator kinerja dapat menjadi alat yang ampuh untuk berbagai tujuan di sektor pemerintah sebagaimana dirangkum oleh Markic (2014) dari berbagai literatur: (a) Pemantauan dan penetapan target; (b) Mengevaluasi dan mereformasi kebijakan,

Perbandingan komparatif yaitu membandingkan kinerja dari beberapa organisasi berbeda; (d) Pengambilan keputusan strategis serta pengambilan keputusan yang lebih terinformasi; (e) Perencanaan dan manajemen strategis dalam pencapaian prioritas strategis pembangunan; (f) Pengalokasian sumber daya; (g) Peningkatan kualitas; (h) Kontrak Kinerja; (i) Pelaporan kemajuan dan pencapaian tujuan yang telah ditetapkan sebelumnya; (j) Bentuk komunikasi dengan publik; (k) Evaluasi efektivitas penyampaian layanan publik; (l) Penghargaan atas keberhasilan serta tindakan korektif untuk menghindari kegagalan berulang.

Keterlibatan pemangku kepentingan dapat berdampak pada praktik pengukuran kinerja, meningkatkan integrasi informasi kinerja, serta membuka peluang kemitraan yang lebih kuat antara pemerintah dan warga (Ho, 2007). Keterlibatan tersebut juga merupakan salah satu dari 3 faktor penting yang menjadi pertimbangan dalam implementasi efektifitas sistem pengkuran kinerja di sektor pemerintah (Goh, 2012). Alfred Tat Kei Ho (2008) mengungkapkan bahwa dengan adanya keterlibatan dapat membantu administrator untuk melihat perspektif lain atas suatu layanan publik yaitu dari warga masyarakat serta pemangku kepentingan lainnya. Keterlibatan pemangku kepentingan dalam pengukuran kinerja merupakan cara untuk memanfaatkan bakat dan keahlian komunitas. Apabila sebaliknya, pemerintah dapat kehilangan kesempatan berharga untuk mengedukasi dan melibatkan mereka dalam dialog tentang pelayanan publik serta berbagai tantangan kompleks yang dihadapi oleh lembaga pemerintah.

Proses melibatkan pemangku kepentingan dalam perancangan serta penyampaian layanan publik dapat memiliki banyak bentuk (Loeffler \& Martin, 2016). Tipologi keterlibatan tersebut terdiri dari (1) Information, informasi merupakan hubungan satu arah antara pemerintah dan warga negara. Pemerintah memberikan informasi kepada warga negara melalui berbagai media, dan demikian sebaliknya warga mengirimkan informasi untuk memicu intervensi pemerintah; (2) Consultation, konsultasi merupakan dialog dua arah antara organisasi publik dengan warga negara, dimana warga diberi hak memberikan pendapat mengenai suatu isu. Namun tidak terdapat jaminan bahwa hasilnya akan menjadi keputusan yang diterapkan; (3) Participation in public decision making, merupakan bentuk partisipasi yang lebih intens antara 
Jurnal Administrasi Negara

ISSN : 2598-4039 (Online)

ISSN : 2302-2221 (Print)
Eny Diana Mudrikah, Roy V. Salomo

Program Magister Ilmu Administrasi

Fakultas Ilmu Administrasi

Universitas Indonesia organisasi publik dan warga dimana masing-masing pihak memiliki peran dalam pengambilan keputusan dan pengaruh atas kebijakan yang ditetapkan; (4) Co-Production of public Services and outcomes, merupakan bentuk paling intensif dari keterlibatan, dimana warga negara dan lembaga publik saling memanfaatkan sumber daya satu sama lain dalam rangka peningkatan layanan publik ataupun tujuan yang hendak dicapai.

Keterlibatan yang baik berarti memperlakukan pemangku kepentingan sebagaimana orang dewasa, dan akan berhasil ketika mampu (1) memberikan informasi, (2) memberi kesempatan untuk mengeluarkan pendapat, menyajikan berbagai pilihan kebijakan, (4) memberikan legitimasi politik, (5) menyenangkan dan memberikan kenyamanan. Proses yang baik tersebut dapat berdampak positif bagi warga negara, komunitas, dan pemerintahan dengan berbagai cara dan mekanisme yang berbeda (Nabatchi \& Leighninger, 2015).

Beberapa upaya keterlibatan pemangku kepentingan dilakukan oleh organisasi sektor publik, antara lain melalui audiensi publik ataupun forum diskusi kelompok (focus group discussion), dimana metode ini menawarkan tingkat interaksi yang tinggi namun relatif memerlukan waktu, biaya, fasilitator yang cukup handal serta hanya menjangkau sebagian kecil pemangku kepentingan saja. Metode lain adalah melalui survei warga sebagai pemangku kepentingan yang dapat menjangkau cakupan lebih luas dengan biaya relatif lebih murah, namun memberikan tingkat interaksi yang kurang mendalam. Oleh karena itu, suatu organisasi memerlukan portofolio pendekatan keterlibatan publik yang seimbang (Loeffler \& Martin, 2016) dalam hal (1) Tujuan keterlibatan dengan pemangku kepentingan maupun warga negara (the objective of engaging); (2) Sumber daya yang tersedia dalam pengelolaan proses keterlibatan (the resources); (3) Skala waktu yang dibutuhkan dalam proses pengambilan keputusan (the timescale); (4) Kapasitas dari pemangku kepentingan yang terlibat (the capacity of respondent).

Penekanan pada penggunaan indikator kinerja juga merupakan elemen kunci Margaret Thatcher dalam upaya meningkatkan produktivitas dan akuntabilitas instansi pemerintah Inggris Raya (Halachmi \& Holzer, 2010). Indikator kinerja berbasis perspektif masyarakat dapat berfungsi untuk mengidentifikasi masalah dan kesulitan yang dihadapi berbagai bidang pemerintahan termasuk pula dalam layanan kesehatan serta kesenjangan dalam kualitas pelayanan, sehingga memungkinkan regulator bidang kesehatan untuk merumuskan strategi dan manajemen yang lebih baik dalam sistem pelayanan kesehatan (Mpinga and Chastonay, 2011). Keberhasilan proses keterlibatan juga bergantung 
Jurnal Administrasi Negara

ISSN : 2598-4039 (Online)

ISSN : 2302-2221 (Print)
Eny Diana Mudrikah, Roy V. Salomo

Program Magister Ilmu Administrasi

Fakultas Ilmu Administrasi

Universitas Indonesia pada penilaian akurat serta kepentingan dari para aktor, saling ketergantungan dalam jejaring kebijakan, maupun perkiraan sumber daya yang dibutuhkan untuk mencapai tujuan keterlibatan. Beberapa literatur terkait partisipasi menunjukkan kebutuhan representasi dari masing-masing pemangku kepentingan (Uittenbroek, et al 2019). Subjek tentang bagaimana pemerintah melibatkan pemangku kepentingan dalam perancangan indikator kinerja di sektor publik merupakan fenomena yang relatif belum banyak diteliti. Pengguna utama informasi kinerja sebagian besar adalah pengelola program, analis anggaran, dan pejabat pemerintah yang terpilih.

Pemangku kepentingan eksternal jarang terlibat secara penuh dalam mendefinisikan, memilih, dan menggunakan pengukuran kinerja. Penelitian ini berupaya mengeksplorasi peran pemangku kepentingan dalam perancangan indikator kinerja sistem pengawasan obat mengacu pada teori keterlibatan (citizen engagament) dari Loeffler \& Martin (2016) berbasis konsep tata kelola publik (public governance) yang mengeksplorasi cara-cara yang dilakukan organisasi domain publik bekerja sama dengan mitra, pemangku kepentingan, warga, serta jejaring mereka, sehingga diperoleh perspektif sejauh mana keterlibatan pemangku kepentingan dalam perancangan indikator kinerja pembangunan di bidang pengawasan obat.

\section{METODE PENELITIAN}

Penelitian ini menerapkan paradigma konstruktivis yang mengembangkan makna subjektif berdasarkan pengalaman masingmasing individu (multiple participant meaning), mencari makna sesuatu di tengah masyarakat tanpa dibebani teori, namun sebagai panduan agar terarah (Creswell \& Creswell, 2018). Fokus paradigma konstruktivis ini adalah mengandalkan sebanyak mungkin perspektif informan tentang situasi yang sedang dipelajari.

Teknik pengumpulan data yang digunakan adalah kualitatif, dimana salah satu karakteristiknya yaitu terdapat kebutuhan untuk mengeksplorasi dan mendekripsikan suatu fenomena (Creswell \& Creswell, 2018). Metode kualitatif mencoba mengembangkan gambaran yang kompleks dari suatu permasalahan yang sedang diangkat dengan melibatkan berbagai perspektif, mengidentifikasi banyak faktor non linier dalam suatu situasi, serta memberikan gambaran kompleks yang muncul. Dalam hal ini, peneliti mengumpulkan data primer yang diperoleh melalui wawancara mendalam dengan konsep pertanyaan yang terstruktur dikaitkan dengan konsep utama penelitian yaitu indikator kinerja dan keterlibatan publik (citizen engagement), bersifat terbuka, serta disusun secara luas dan umum sehingga para informan dapat membangun makna sebuah situasi dan memberikan 
Jurnal Administrasi Negara

ISSN : 2598-4039 (Online)

ISSN : 2302-2221 (Print)
Eny Diana Mudrikah, Roy V. Salomo

Program Magister Ilmu Administrasi

Fakultas Ilmu Administrasi

Universitas Indonesia gambaran mengenai perspektif pemangku kepentingan terhadap indikator kinerja pengawasan obat. Selain itu, didukung pula oleh data sekunder yang berasal dari dokumen instansi terkait, serta studi pustaka dari berbagai jurnal.

Kriteria kesesuaian lokus sebagaimana yang disebutkan oleh Ianniello, et al (2019) bergantung tujuan yang hendak dicapai melalui keterlibatan publik antara lain yaitu menemukan ide-ide inovatif dalam perancangan indikator kinerja melalui partisipan terpilih dengan ide-ide yang beragam, menangani kebuntuan situasi yang memerlukan publik dengan minat khusus dalam pemecahan masalah, serta mendapatkan dukungan publik yang menyiratkan pemilihan berdasarkan kombinasi keragaman dan keterwakilan. Berkaitan dengan hal tersebut, lokus penelitian berikut terdiri dari pemangku kepentingan internal dan eksternal BPOM RI terkait dengan indikator kinerja pengawasan obat pada periode bulan April-Mei 2021.

Jumlah informan tergantung pada kedalam informasi yang hendak diketahui, tujuan penelitian, hal-hal dipertaruhkan, hal-hal yang bermanfaat, kredibiltas informasi, serta pertimbangan waktu dan sumber daya yang tersedia. Terdapat trade off antara keluasan (breadth) dan kedalaman (depth) (Patton, 2014). Keseluruhan jumlah informan penelitian terdiri dari 22 orang berdasarkan purposeful random sampling. Sebagai Informan Kunci dengan pertimbangan mengetahui informasi secara umum serta pihak yang mengetahui secara konseptual adalah dari Biro Perencanaan. Sementara Informan Utama yaitu pihak yang mengetahui informasi secara detail sekaligus sebagai aktor utama adalah perwakilan dari berbagai fungsi dari kedeputian teknis terkait yang meliputi standarisasi, pengawasan produksi maupun distribusi, pengawasan mutu, serta fungsi penindakan obat.

$$
\text { Pada tingkat Informan }
$$

Pendukung yang dapat memberikan informasi tambahan yang bermanfaat dan relevan serta merupakan pihak yang terkait dengan Informan Utama yaitu dari Inspektorat maupun pemangku kepentingan eksternal antara lain pemerintah (Kementerian Perencanaan Pembangunan Nasional, Badan Pusat Statistik), akademisi (bidang farmakologi dari Universitas Indonesia maupun bidang Statistik dari Institut Teknologi Sepuluh Nopember Surabaya), asosiasi profesi (Ikatan Dokter Indonesia, Ikatan Apoteker Indonesia), tenaga kesehatan (Rumah Sakit Cipto Mangunkusumo), mitra sektor komersial bidang farmasi (GP Farmasi, PT. Enseval Putera Mega Trading), serta dari media (Media News Center).

Pengolahan data pada penelitian konstruktivis dilakukan melalui peninjauan data hasil wawancara dan 
Jurnal Administrasi Negara

ISSN : 2598-4039 (Online)

ISSN : 2302-2221 (Print)
Eny Diana Mudrikah, Roy V. Salomo

Program Magister Ilmu Administrasi

Fakultas Ilmu Administrasi

Universitas Indonesia kemudian membandingkannya dengan seluruh subset. Validasi hasil penelitian dilakukan melalui triangulasi antara data primer dan sekunder sehingga data yang diperoleh akurat dan dapat diandalkan. Selain itu juga pengecekan berdasarkan informan dari berbagai latar belakang akademis dan profesi sehingga diperoleh berbagai perspektif yang saling membangun. Dalam paradigma konstruktivis, dilakukan analisis kualitatif untuk memahami pengalaman populasi sasaran. Peneliti mengartikan temuan sebagai representasi langsung dari konstruksi sosial alih-alih menghubungkan temuan dengan fakta dalam literatur ilmiah, dengan kata lain tidak memaksakan data ke dalam kategori yang dibuat sebelumnya, sehingga lebih memungkinkan untuk interpretasi dan pemahaman terbuka.

\section{HASIL DAN PEMBAHASAN}

Perubahan dari konsep pemerintah (government) menuju tata kelola pemerintahan (governance) menghendaki seluruh pemangku kepentingan untuk dapat memberikan perannya secara lebih inovatif dalam pembentukan keputusan dan berkontribusi pada hasil (outcomes) yang diharapkan oleh publik (Loeffler, 2016). Hal ini berimbas pula pada sistem pengukuran kinerja dimana pada konsep pemerintah (goverment), sistem yang diterapkan merupakan hasil benchmarking, proses internal atau kinerja organisasi terhadap pemerintahan lainnya. Namun dalam konsep tata kelola pemerintahan (governance), melibatkan kelompok pemangku kepentingan dalam pendefinisian standar kinerja. Sebagaimana telah tertuang pula salah satu isu strategis kelembagaan birokrasi dalam Rancangan Teknokratik RPJMN 2020-2024, yang mengarah pada kelembagaan dan proses bisnis yang lebih sederhana, responsif, adaptif, dan membuka ruang peran serta publik dalam pemerintahan.

\section{Indikator Kinerja Pengawasan Obat Berbasis Keterlibatan Publik (Citizen Engagement)}

Berdasarkan hasil wawancara dengan berbagai pemangku kepentingan internal serta triangulasi dokumen, diperoleh perspektif karakteristik indikator kinerja utama pengawasan obat berdasarkan Parmenter (2020) sebagai berikut:

a) Non-finansial (Non-financial), karakteristik ini terpenuhi karena indikator kinerja pengawasan obat tidak diukur dalam denominasi mata uang, namun dalam bentuk persentase hasil pengawasan.

b) Diukur secara berkala (Timely), capaian indikator kinerja utama pengawasan obat diukur setiap bulan, serta dipantau dan dievaluasi secara berkala setiap triwulan.

c) Fokus utama dari aktifitas organisasi (CEO Focus), pimpinan organisasi memiliki komitmen kuat terhadap 
Jurnal Administrasi Negara

ISSN : 2598-4039 (Online)

ISSN : 2302-2221 (Print)
Eny Diana Mudrikah, Roy V. Salomo

Program Magister Ilmu Administrasi

Fakultas Ilmu Administrasi

Universitas Indonesia pencapaian target kinerja persentase obat memenuhi syarat ditunjukkan melalui arahan kebijakan secara berjenjang ke dalam internal BPOM termasuk langkah inovatif pendukung capaiannya.

d) Sederhana dan mudah dipahami (Simple), indikator kinerja pembangunan dibidang pengawasan obat cukup sederhana dan mudah dipahami dari segi formulasi kalimat, namun tidak demikian halnya dengan sistem pengukuran serta tindakan korektif yang diperlukan.

e) Berbasis tim (Team Based), perumusan indikator kinerja pengawasan obat maupun evaluasi capaiannya menghubungkan tanggung jawab antara tim perencanaan, tim pemantauan dan evaluasi, tim pelaporan, tim teknis pengawasan, maupun pemangku kepentingan terkait.

f) Berdampak signifikan bagi keberhasilan organisasi (significant impact), keberhasilan organisasi diukur dari kinerja ataupun manfaat yang dapat secara langsung dirasakan oleh masyarakat. Indikator kinerja persentase obat memenuhi syarat dapat mencerminkan aktivitas utama organisasi serta capaian visi misi BPOM apabila pengukurannya dilakukan dengan sistem yang tepat.

g) Hampir tidak memiliki konsekuensi negatif (Limited darkside), indikator persentase obat memenuhi syarat dapat menimbulkan konsekuensi negatif khususnya masyarakat, apalagi dengan target yang berada disekitar $80 \%$ yang menunjukkan bahwa sekitar $20 \%$ obat yang beredar di Indonesia adalah tidak memenuhi syarat. Sedangkan pemenuhan persyaratan merupakan syarat mutlak dari suatu produk dapat beredar. Konsekuensi negatif juga dapat berdampak pada BPOM yang dipersepsikan tidak mampu melakukan tanggung jawab pengawasan dengan baik sehingga sekitar $20 \%$ obat di peredaran tidak memenuhi syarat.

Berdasarkan uraian tersebut, diketahui bahwa karakteristik indikator kinerja utama telah terpenuhi selain aspek tidak memiliki konsekuensi negatif. Sebagian besar pemangku kepentingan internal memiliki perspektif bahwa indikator "persentase obat memenuhi syarat" tersebut telah sesuai dalam menggambarkan kinerja pembangunan di bidang pengawasan obat.

Namun, sebagian berpandangan bahwa kinerja pengawasan obat mencakup aspek yang sangat luas tidak hanya sampling dan pengujian produk, sehingga indikator kinerja utama seyogyanya dapat melingkupi hasil dari berbagai aspek sistem pengawasan obat, salah satu alternatifnya yaitu indikator yang berbentuk indeks dengan angka pembentuknya yang merupakan komposit dari berbagai komponen sistem pengawasan. 
Jurnal Administrasi Negara

ISSN : 2598-4039 (Online)

ISSN : 2302-2221 (Print)
Eny Diana Mudrikah, Roy V. Salomo

Program Magister Ilmu Administrasi

Fakultas Ilmu Administrasi

Universitas Indonesia

\section{Mengenai definisi operasional "obat" pada indikator kinerja "persentase obat memenuhi syarat" yang mencakup obat tradisional, suplemen kesehatan, dan kosmetik, hal tersebut didasarkan pada Perpres No. 80} Tahun 2017 tentang Badan Pengawas Obat dan Makanan, dimana pada pasal 2 ayat 1 disebutkan bahwa "BPOM mempunyai tugas menyelenggarakan tugas pemerintahan di bidang pengawasan Obat dan Makanan sesuai dengan ketentuan peraturan perundangundangan". Disambung dengan ayat 2 yang menyebutkan bahwa "Obat dan Makanan sebagaimana dimaksud pada ayat (1) terdiri atas obat, bahan obat, narkotika, psikotropika, prekursor, zat adiktif, obat tradisional, suplemen kesehatan, kosmetik, dan pangan olahan". Berdasarkan hal tersebut, segala jenis komoditi yang disebutkan pada ayat 2 selain pangan olahan, merupakan penjabaran dari definisi operasional obat. Dengan demikian, proses perhitungan target maupun capaiannya menggunakan pembobotan terhadap masing-masing unsur pembentuknya.

Mengidentifikasi dan memilih kriteria indikator kinerja yang sesuai merupakan pertimbangan penting dalam mengevaluasi kinerja organisasi sektor publik. Kriteria yang dipilih serta proses evaluasi akan sangat tergantung pada perspektif yang diambil. Stakeholder yang berbeda cenderung menekankan kriteria yang berbeda
(Woolum, 2011). Tantangannya adalah untuk menggabungkan penilaian kinerja yang berbeda dari semua pemangku kepentingan.

\section{Berdasarkan}

perspektif pemangku kepentingan eksternal diperoleh gambaran mengenai indikator kinerja pembangunan di bidang pengawasan obat terkait dengan aspek kemanfaatan serta kejelasan dan kemudahan untuk dipahami bagi warga masyarakat bahwa dari akademisi farmakologi menilai bahwa indikator tersebut masih perlu diperjelas mengenai persyaratannya. Sementara dari berbagai kalangan lain menilai bahwa indikator tersebut kurang tersosialisasi dengan baik. Masyarakat lebih melihat pada dampak kinerja nyata terkait pengawasan obat beredar di masyarakat, informasi mengenai obatobatan yang ditarik dari peredaran, serta terkait aspek lain terkait keamanan obat. Ketika digali lebih lanjut mengenai indikator kinerja pembangunan di bidang pengawasan obat yang menetapkan Persentase Obat Memenuhi Syarat sebesar $80 \%$ pada tahun 2020 hingga capaian sebesar 92,3\% pada tahun 2024, berbagai pemangku kepentingan dari kalangan farmasis menilai bahwa hal tersebut sudah cukup bagus dengan justifikasi bahwa penyesuaian tersebut berdasarkan pertimbangan perubahan kerangka sampling dan reformulasi penentuan kriteria produk memenuhi syarat, sehingga menjadi lebih ketat. Dari 
Jurnal Administrasi Negara

ISSN : 2598-4039 (Online)

ISSN : 2302-2221 (Print)
Eny Diana Mudrikah, Roy V. Salomo

Program Magister Ilmu Administrasi

Fakultas Ilmu Administrasi

Universitas Indonesia kalangan akademisi statistik justru menilai bahwa angka tersebut terlalu rendah apabila didasarkan pada tren selama sepuluh tahun terakhir yang berkisar di angka $98 \%$. Namun apabila sampel yang diambil sebagai data sudah cukup representatif serta konsep dan definisi yang digunakan sudah terstandar, maka hal tersebut dapat dipertanggungjawabkan secara ilmiah. Apabila belum memenuhi kriteria tersebut, seyogyanya perlu dilakukan perbaikan metodologi sampel maupun konsep dan definisinya. Perlu dipertimbangkan pula untuk pemanfaatan big data dalam memperoleh angka indikator tersebut.

Selanjutnya, perspektif mengenai indikator kinerja pembangunan pengawasan obat yang dalam perhitungan capaiannya mencakup obat tradisional, suplemen kesehatan, dan kosmetik, para pemangku kepentingan dari berbagai kalangan sepakat menilai bahwa cakupan tersebut sangat perlu dengan mempertimbangkan pergeseran gaya hidup kepada kebutuhan tersier dalam rangka preventif dan estetika sehingga bermunculan produk-produk obat tradisional, suplemen kesehatan, dan kosmetik secara masif. Ditambahkan pula dari aspek pemenuhan standar dari ketiga produk tersebut masih belum seketat obat, selain dalam pemakaiannya pun masih banyak disalahgunakan. Sehingga dalam hal ini diperlukan dukungan pemerintah dalam hal sumber daya manusia, sarana prasarana termasuk laboratorium, anggaran, serta edukasi kepada masyarakat yang lebih luas. Namun, hal tersebut berbeda dengan pandangan masyarakat awam secara luas, yang mana suplemen kesehatan dan kosmetik tidak sesuai apabila digabungkan dengan obat, karena perbedaan fungsinya yang mana obat lebih mengarah kepada kuratif penyembuhan sementara kosmetik mengarah pada fungsi estetika.

Pada dasarnya, indikator yang baik adalah yang memiliki tingkat validitas dan reliabilitas tinggi, yaitu indikator yang tidak bias sehingga menggambarkan ukuran yang tepat. Indikator kinerja yang reliabel berarti bahwa indikator tersebut objektif, tepat, dan dapat diandalkan. Aspek lain dari reliabilitas adalah konsistensi dari waktu ke waktu, artinya dengan cara yang sama pada waktu yang berbeda, pengukuran dapat menghasilkan data yang cenderung sama (Poister, Aristigueta, \& Hall, 2015).

$$
\text { Praktisi dan akademisi }
$$

hendaknya tidak hanya memperhatikan bagaimana hasil kinerja digunakan, tetapi juga mengkaji bagaimana proses penghitungan indikator kinerja dapat dirancang untuk meningkatkan hasil kinerja secara laten, yaitu apabila organisasi mampu merefleksikan informasi kinerja melalui pembinaan dan pengaturan budaya kerja, aspirasi, dan keyakinan sehingga diharapkan mampu menjawab kritik terhadap indikator kinerja yang pada umumnya 
Jurnal Administrasi Negara

ISSN : 2598-4039 (Online)

ISSN : 2302-2221 (Print)
Eny Diana Mudrikah, Roy V. Salomo

Program Magister Ilmu Administrasi

Fakultas Ilmu Administrasi

Universitas Indonesia menganggap bahwa informasi kinerja tidak akurat, bias atau tidak valid. Meskipun awalnya organisasi hanya melakukan perubahan tersebut sebagai bagian dari proses perhitungan indikator kinerja, namun pada akhirnya berdampak pada peningkatan manajemen risiko internal maupun hasil kinerja organisasi (Dooren \& Kempeneer, 2019). Hal yang tidak kalah penting, kemampuan pimpinan untuk membangun jaringan antar aktor, merupakan kunci keberhasilan dalam merancang dan secara simultan pengimplementasian program keterlibatan masyarakat (Kushandajani \& Permana, 2020).

\section{Citizen Engagement Berbasis Pemangku Kepentingan Internal}

Selanjutnya, terkait dengan keseimbangan portofolio pendekatan keterlibatan publik dalam penetapan indikator kinerja pengawasan obat, diperoleh hasil tinjauan dari perspektif pemangku kepentingan internal sebagaimana berikut:

a) Tujuan keterlibatan, BPOM telah memiliki pemahaman mengenai pentingnya melibatkan pemangku kepentingan dalam perancangan indikator kinerja pengawasan obat yang mana pada prosesnya telah melalui penjaringan aspirasi secara top-down planning maupun bottomup planning dari berbagai pemangku kepentingan meliputi Kementerian Perencanaan Pembangunan
Nasional, Badan Pusat Statistik, akademisi, pelaku usaha, asosiasi profesi kesehatan, serta lembaga swadaya masyarakat. Namun demikian, masih terdapat keraguan pada sebagian pihak bahwa BPOM telah mengkomunikasikan pentingnya keterlibatan publik dalam penetapan indikator kinerja pengawasan obat kepada pemangku kepentingan.

b) Sumber daya yang tersedia, BPOM mengalokasikan waktu dan pikiran untuk melibatkan publik dalam penetapan indikator kinerja pengawasan obat yang mana hal ini tercermin dari keterlibatan secara aktif dalam berbagai forum pertemuan bersama Kementerian Perencanaan Pembangunan Nasional dan narasumber ahli dalam rangka pembahasan rancangan indikator pengawasan obat. Demikian pula terkait fasilitasi media, sarana, maupun prasarananya. Satu hal yang menjadi ganjalan adalah bahwa penetapan indikator kinerja tersebut tidak melalui konsultasi atau uji publik secara luas sehingga menimbulkan persepsi bahwa keterlibatan belum sepenuhnya berjalan dengan baik.

c) Rentang waktu proses, Alur proses telah berupaya disiapkan oleh BPOM untuk memberikan kesempatan kepada para pemangku kepentingan untuk turut terlibat dalam penetapan indikator kinerja pengawasan obat 
Jurnal Administrasi Negara

ISSN : 2598-4039 (Online)

ISSN : 2302-2221 (Print)
Eny Diana Mudrikah, Roy V. Salomo

Program Magister Ilmu Administrasi

Fakultas Ilmu Administrasi

Universitas Indonesia dengan rentang waktu yang cukup lebar. Hal tersebut sebagaimana tertuang dalam prosedur operasi standar perencanaan indikator kinerja.

d) Kapasitas pemangku kepentingan, berbagai pihak masih meragukan bahwa BPOM telah menyiapkan kriteria pemangku kepentingan yang dapat terlibat dalam penetapan indikator kinerja pengawasan obat. Ditambahkan pula bahwa pakar dengan keahlian khusus dalam bidang perancangan indikator kinerja sektor publik yang acapkali bersifat teknis dan birokratif belum banyak ditemui, dengan merujuk implementasi bahwa pemangku kepentingan yang dilibatkan dalam perancangan indikator kinerja pada umumnya berasal dari spesifikasi bidang statistik, ekonomi, farmakologi, kesehatan masyarakat, serta kebijakan publik.

\section{Citizen Engagement Berbasis Pemangku Kepentingan Eksternal Portofolio pendekatan} keterlibatan publik dalam penetapan indikator kinerja pengawasan obat dari perspektif pemangku kepentingan eksternal diperoleh hasil sebagaimana berikut:

a) Tujuan keterlibatan, masyarakat tidak akan meluangkan waktu untuk turut terlibat tanpa mengetahui nilai manfaat maupun konsekuensinya. Para pemangku kepentingan yang akan terlibat dalam perancangan indikator kinerja pengawasan obat telah memahami visi misi BPOM sebagai lembaga pemerintah dibidang pengawasan obat. Selain itu, mereka juga telah memahami pentingnya BPOM melibatkan publik dalam penetapan indikator kinerja pengawasan obat. Mereka berpendapat bahwa masyarakat sebagai pengguna obat (end-user) perlu memiliki keterwakilan dan didengar masukannya dalam hal penetapan indikator kinerja pengawasan obat. Masyarakat atau publik yang dimaksud pun tentunya adalah yang memiliki keahlian pendukung dalam penetapan indikator tersebut, seperti akademisi, kementerian dan lembaga terkait, pelaku usaha dibidang farmasi, sehingga pada akhirnya diperoleh indikator yang tepat.

b) Ketersediaan Sumber Daya, ketika digali lebih jauh mengenai kesediaan, dari akademisi bidang farmakologi serta asosiasi bidang kefarmasian bersedia meluangkan waktu dan pikiran untuk dilibatkan dalam penetapan indikator kinerja pengawasan obat, dengan pertimbangan bahwa mereka merupakan bagian dari masyarakat utamanya dibidang kesehatan serta sebagai wakil masyarakat yang benar-benar memiliki keahlian dan fokus pada aspek obat. Hal tersebut dinilai penting sebagai bentuk 
Jurnal Administrasi Negara

ISSN : 2598-4039 (Online)

ISSN : 2302-2221 (Print)
Eny Diana Mudrikah, Roy V. Salomo

Program Magister Ilmu Administrasi

Fakultas Ilmu Administrasi

Universitas Indonesia $\begin{array}{lrr}\text { kontribusi } & \text { keilmuan } & \text { untuk } \\ \text { peningkatan } & \text { kualitas } & \text { kinerja } \\ \text { pengawasan } & \text { sehingga } & \text { mampu }\end{array}$ memberikan dampak perlindungan bagi masyarakat. Pada sisi lain juga dapat semakin meningkatkan kepatuhan (compliance) bagi para pelaku usaha di bidang obat serta keselarasan dengan tujuan dari BPOM dalam hal pengawasan obat beredar di Indonesia.

c) Rentang waktu alur proses, sebagian besar pemangku kepentingan masih belum mendapatkan informasi ataupun gambaran secara jelas mengenai alur proses keterlibatan dalam penetapan indikator kinerja pengawasan obat. Namun pada dasarnya, mereka bersedia apabila diberikan kesempatan untuk turut terlibat dalam perencanaan indikator kinerja pengawasan obat.

d) Kapasitas Pemangku Kepentingan, para akademisi bidang farmakologi, mitra sektor komersial bidang farmasi, tenaga kesehatan, asosiasi profesi kefarmasian menilai bahwa mereka cukup kompeten serta memiliki motivasi yang kuat untuk turut serta dalam penetapan indikator kinerja pengawasan obat dikaitkan dengan spesifikasi bidang yang digeluti.

\section{Organisasi}

senantiasa

memerlukan aktor yang memiliki nilai budaya dengan perspektif berbeda (Kushandajani \& Permana, 2020). Sebagaimana pula, keterlibatan dapat mencakup berbagai kelompok pemangku kepentingan yang berbeda. Dalam beberapa kasus, keterlibatan level pertama mungkin cocok. Di lain kasus, perlu adanya pelibatan publik secara keseluruhan. Terdapat banyak sekali teknik dalam keterlibatan publik, namun yang paling penting adalah alat yang digunakan oleh organisasi sesuai dengan tujuan, ruang lingkup, dan kapasitas kelompok yang akan dilibatkan organisasi untuk berkoordinasi (Loeffler \& Martin, 2016). Merujuk keseimbangan portofolio pendekatan keterlibatan publik berbasis pemangku kepentingan eksternal maupun internal tersebut diperoleh gambaran bahwa tentunya forum diskusi kelompok dengan tingkat interaksi yang tinggi lebih sesuai untuk dilakukan dalam memperoleh rancangan indikator kinerja pembangunan di bidang pengawasan obat.

Ditambahkan pula bahwa, berdasarkan hasil wawancara pemangku kepentingan eksternal diperoleh perspektif bahwa indikator kinerja bukan merupakan hal yang mudah dipahami oleh sebagian besar elemen masyarakat. Hal ini sebagaimana telah dikemukakan oleh Ianniello, et al (2019) mengenai tiga rangkaian kendala potensial dalam keterlibatan publik yaitu:

a) Faktor kontekstual, seperti defisit dan asimetri informasi serta sikap pejabat publik, dengan menimbang perspektif bahwa indikator kinerja 
Jurnal Administrasi Negara

ISSN : 2598-4039 (Online)

ISSN : 2302-2221 (Print)
Eny Diana Mudrikah, Roy V. Salomo

Program Magister Ilmu Administrasi

Fakultas Ilmu Administrasi

Universitas Indonesia ini lebih diperlukan bagi pemerintah dalam mengambil kebijakan. Masyarakat secara luas kurang memiliki rekognisi serta menaruh perhatian terhadap informasi terkait indikator tersebut, karena pada umumnya mereka lebih melihat pada kinerja riil seperti upaya pengawasan yang konsisten dan terus menerus pada obat-obat yang beredar di masyarakat, sosialisasi dan edukasi terkait penggunaan obat secara lebih dekat dan intens kepada masyarakat, serta penindakan tegas atas pelanggaran di bidang obat.

b) Pengaturan organisasi, khususnya kriteria representasi masyarakat dan desain proses; BPOM telah mendefinisikan dalam peta proses bisnisnya bahwa pemerintah, pelaku usaha, masyarakat, dan akademisi sebagai sumber input, namun belum secara spesifik disebutkan mengenai kriterianya. Demikian pula apabila dikaitkan dengan perancangan indikator kinerja pengawasan obat yang tentunya memerlukan masyarakat (citizen) dengan kualifikasi khusus. Desain proses juga sangat penting kaitannya dengan pilihan dan implementasi alat dialog dalam dinamika keterlibatan. Definisi yang membingungkan dari mekanisme keterlibatan dapat memberikan dampak kurang menguntungkan dari inisiatif partisipasi (Yang \&
Pandey, 2011) dalam Ianniello, et al (2019).

c) Pola manajemen proses, termasuk dinamika kelompok dan kualitas kolaborasi. Pemerintah dapat dengan mudah mengumpulkan lebih banyak informasi terkait kinerja dari warga yang aktif menggunakan atau membutuhkan pemerintah, sehingga target representasi kelompok dalam upaya kolaborasi pengumpulan informasi terkait penggambaran kinerja BPOM sebagai lembaga pemerintahan dapat terpenuhi.

Demikian pula tantangan yang dikemukakan oleh beberapa peneliti dalam Afzalan \& Muller (2018) yaitu mengenai kurangnya minat pemangku kepentingan untuk terlibat karena akses atau masalah lain terkait waktu dan tempat atau bias pribadi serta rendahnya tingkat kepercayaan dan keyakinan terhadap perencana dan pejabat publik. Selain itu pula terkait dengan tingginya biaya, waktu, staf, serta sumber daya yang dibutuhkan untuk mengkoordinasikan dan menganalisis proses keterlibatan. Perencana dan pembuat kebijakan dalam mengelola proses keterlibatan harus menyeimbangkan tujuan dan tekanan yang sering tampak seperti aturan pemerintah, serta ketidakpastian dan keraguan tentang kegunaan proses partisipatif tersebut.

Ketika digali lanjut mengenai tingkat peminatan keterlibatan pemangku kepentingan dalam 
Jurnal Administrasi Negara

ISSN : 2598-4039 (Online)

ISSN : 2302-2221 (Print)
Eny Diana Mudrikah, Roy V. Salomo

Program Magister Ilmu Administrasi

Fakultas Ilmu Administrasi

Universitas Indonesia perancangan indikator kinerja $\mathrm{BPOM}$, diketahui bahwa dari perspektif akademisi non-farmakologi, tenaga kesehatan, mitra sektor komersial bidang farmasi, serta media berada pada tingkat ingin mengetahui hal-hal yang telah dilakukan BPOM, namun cukup melihat perkembangannya saja. Sementara dari perspektif akademisi bidang farmakologi, asosiasi profesi bidang kefarmasian berada pada level peminatan keterlibatan yang lebih tinggi yaitu ingin turut andil atas hal-hal yang dilakukan BPOM dalam penyediaan layanan publik, termasuk dalam perencanaan indikator kinerja.

Tipologi keterlibatan antara BPOM dengan pemangku kepentingan dalam rangka perancangan indikator kinerja pengawasan obat tersebut telah berada pada level 3 (tiga) yaitu Participation in public decision making, yang merupakan bentuk keterlibatan lebih intens antara organisasi publik dan pemangku kepentingan dimana masingmasing pihak memiliki peran dalam pengambilan keputusan dan pengaruh atas kebijakan yang ditetapkan. Hal tersebut ditunjukkan dari adanya interaksi BPOM dengan pemangku kepentingan dalam penetapan indikator kinerja pengawasan obat, dimana masukan dari pemangku kepentingan tersebut mempengaruhi keputusan akhir BPOM. Terutama dalam hal ini adalah para akademisi, praktisi lapangan, serta sektor pemerintahan terkait dalam bidang perencanaan pembangunan.
Berdasarkan uraian tersebut, keterlibatan publik sebagai sebuah pendekatan bottom-up yang merupakan penyeimbang atas perencanaan indikator kinerja yang bersifat topdown, dapat lebih diintensifkan dalam pelaksanaannya. Sebagai bentuk implementasinya, sebagaimana dijelaskan dalam Afzalan \& Muller (2018), langkah-langkah penerapan metode partisipatif adalah dimulai dari menentukan tujuan, memperjelas populasi sasaran, memfasilitasi keterlibatan, mengembangkan pedoman digital yang sesuai, serta membuat peta jalan. Syarat warga negara (citizen) sendiri memiliki beberapa arti yang berbeda, antara lain mencerminkan hak dan tanggung jawab hukum individu sebagaimana didefinisikan dalam konstitusi dan undang-undang yang mengartikulasikan kualifikasi, kewajiban, dan hak warga negara (Callahan, 2007).

Definisi yang lain menyebutkan bahwa kewarganegaraan mencerminkan konsep sosiologis yang lebih luas sebagai anggota komunitas yang lebih besar, seorang penghuni tempat tertentu, dan karena itu tidak mengecualikan anggota masyarakat yang menurut tempat lahir tidak berhak atas keistimewaan atau terikat oleh tanggung jawab yang secara hukum terkait dengan kewarganegaraan formal. Kewarganegaraan sebagai kebajikan membutuhkan rasa tanggung jawab dan pengabdian sebagai warga negara dalam komunitas dan negara, 
Jurnal Administrasi Negara

ISSN : 2598-4039 (Online)

ISSN : 2302-2221 (Print)
Eny Diana Mudrikah, Roy V. Salomo

Program Magister Ilmu Administrasi

Fakultas Ilmu Administrasi

Universitas Indonesia serta dedikasinya untuk perbaikan kondisi masyarakat.

Pemangku

kepentingan

(stakeholders) merupakan warga negara (citizen) sebagai penerima layanan pemerintah, berada pada posisi terbaik untuk menilai bidang pemerintahan mana yang berfungsi dengan baik dan mana yang membutuhkan perbaikan. Kelompok pemangku kepentingan sebagai populasi sasaran keterlibatan publik khususnya dalam bidang pengawasan obat terkait dengan aspek representasi, antara lain dapat berasal dari kategori profesional/tenaga kesehatan, pemerintah (pusat ataupun daerah), asosiasi profesi utamanya bidang kesehatan, akademisi (dosen, peneliti, dll), media, mitra sektor komersial bidang farmasi, konsumen/organisasi perwakilan konsumen, maupun masyarakat umum/lembaga swadaya masyarakat. Pengkategorian tersebut merupakan kompilasi dari beberapa literatur mengenai jenis pemangku kepentingan yang seyogyanya dilibatkan dalam sektor publik sehingga diperoleh keseimbangan indikator dari berbagai perspektif pemangku kepentingan.

Bagi negara-negara berkembang, pengintegrasian antara keterlibatan pemangku kepentingan dengan pengukuran kinerja seringkali dianggap tugas yang menakutkan, karena terkait dengan akuntabilitas publik yang belum sesuai harapan, penyalahgunaan wewenang, pengendalian korupsi yang belum efektif, serta rendahnya tingkat transparansi (Yang \& Wu, 2013). Terlepas dari nilai keterlibatan publik, administrator pemerintah tetap perlu melakukan pengelolaan dan warga negara tidak dapat menggantikan regulator. Warganegara sebagai pemangku kepentingan dapat menyumbangkan ide-ide segar dan perspektif baru dalam permasalahan tata kelola organisasi publik, tetapi pada akhirnya tetap harus bergantung atau bekerja sama dengan pemerintah untuk mengimplementasikan gagasan tersebut. Keterlibatan pemangku kepentingan dalam pengukuran kinerja tidak selalu menjamin layanan yang lebih baik dan kinerja yang lebih memuaskan, namun dapat menyoroti sistem dari perspektif warga sehingga diperoleh gambaran yang lebih utuh (Dooren, Bouckaert, \& Halligan, 2015).

Keterlibatan pemangku kepentingan menawarkan berbagai manfaat potensial tetapi juga menghadirkan tantangan yang cukup besar pula. Penting bagi pembuat kebijakan dan pengelola layanan publik untuk mengalokasikan waktu dan pikiran terbuka ketika mengembangkan sistem administratif organisasi melalui keterlibatan publik. Keterlibatan warga dalam pengukuran kinerja juga bisa sangat rapuh. Hal ini tidak hanya memerlukan pemerintah yang siap mengambil risiko dan membuat masalah kinerja pemerintah lebih transparan kepada publik, tetapi juga 
Jurnal Administrasi Negara

ISSN : 2598-4039 (Online)

ISSN : 2302-2221 (Print)
Eny Diana Mudrikah, Roy V. Salomo

Program Magister Ilmu Administrasi

Fakultas Ilmu Administrasi

Universitas Indonesia membutuhkan pemimpin komunitas meluangkan waktu dan sumber daya untuk mendukung program, serta bekerja sama dengan pejabat pemerintah dalam mempelajari masalah kinerja yang seringkali bersifat sangat teknis dan birokratis.

\section{PENUTUP}

Kebijakan kesehatan masyarakat bertujuan untuk memelihara dan meningkatkan kesehatan warga sehingga seyogyanya pelaksanaanya didasarkan pada data dan indikator kinerja yang relevan tentang status kesehatan, gaya hidup dan kebiasaan kesehatan, kondisi hidup dan kerja, faktor demografis dan sosial budaya. Sebagaimana dalam layanan publik lainnya, memilih indikator kinerja yang sesuai memungkinkan regulator sistem layanan kesehatan untuk bertransformasi ke dalam bentuk yang lebih sesuai dalam pengambilan keputusan.

Tidak seluruh pemangku kepentingan (stakeholders) dapat secara langsung memiliki keterlibatan aktif dalam proses perancangan indikator kinerja pembangunan, namun harus memenuhi prasyarat nilai dan pengetahuan serta mampu melakukannya. Jika tidak, keterlibatan tersebut dapat mengakibatkan kualitas keputusan administrasi publik dalam hal ini adalah perancangan indikator kinerja yang justru semakin tidak terarah. Dengan demikian, kontribusi akademis sangat diperlukan dalam perencanaan sistem keterlibatan aktif. Pemerintah mungkin sangat efektif dan mampu melaksanakan tugas dan tanggungjawab dengan metode yang cukup konstruktif dan efisien, namun tanpa mengkomunikasikan keberhasilan tersebut kepada publik, maka akan dapat menciptakan kesenjangan persepsi kinerja yang tidak diinginkan.

Deregulasi sistem tentunya tidak terbebas dari beberapa efek samping. Beberapa tindakan biasanya diambil untuk menangani dampak tersebut. Hal yang sama juga berlaku dalam menggalakkan keterlibatan pemangku kepentingan. Reformasi administrasi pemerintahan yang mendorong pemangku kepentingan turut terlibat memerlukan desain kelembagaan pembangunan dan keberhasilannya bergantung pada kontribusi pembuat kebijakan serta akademisi. Sebagaimana dikemukakan oleh Suebvises (2018), bahwa peran pemerintah harus diubah dari mengontrol dan mengarahkan menjadi berkolaborasi, memberdayakan, dan melibatkan masyarakat sipil. Pemerintah tidak lagi menjadi aktor sentral pemerintahan ketika menempatkan para pemangku kepentingan yang mencakup masyarakat sipil, jaringan sosial, organisasi non-pemerintah, dan entitas swasta sebagai mitra dalam pemerintahan. Tujuan utamanya adalah membangun modal sosial yang kuat 
Jurnal Administrasi Negara

ISSN : 2598-4039 (Online)

ISSN : 2302-2221 (Print)
Eny Diana Mudrikah, Roy V. Salomo

Program Magister Ilmu Administrasi

Fakultas Ilmu Administrasi

Universitas Indonesia dimana ada kepercayaan antar aktor serta menghormati satu sama lain.

Serangkaian rekomendasi yang dapat dipertimbangkan dalam upaya keberhasilan keterlibatan pemangku kepentingan dalam perancangan indikator kinerja pengawasan obat sebagaimana juga telah dikemukakan oleh Ianniello,et al (2019) antara lain: (1) Dukungan keragaman dan keterwakilan dalam pemilihan peserta; (2) Penggunaan berbagai metode partisipatif; (3) Pelibatan fasilitator yang berpengetahuan; (4) Membangun jaringan pendukung serta kapasitas kolaboratif dengan lembaga utama; (5) Pengembangan desain proses yang peka terhadap konteks.

\section{REFERENSI}

Afzalan, N., Muller, B. (2018). Online Participatory Technologies: Opportunities and Challenges for Enriching Participatory Planning. Journal of The American Planning Association, 84(2), 162-177. doi:10.1080/01944363.2018.14340 10

Badan Pengawas Obat dan Makanan. (2020). Laporan Kinerja Badan Pengawas Obat dan Makanan Tahun 2019. Jakarta: BPOM

Callahan, K. (2007). Elements of Effective Governance: Measurement, Accountability and Participation. Boca Raton, FL: Taylor \& Francis

Creswell, J. W., \& Creswell, J. D. (2018). Research Design: Qualitative, Quantitative, and Mixed Methods Approaches. Fifth edition. Los Angeles: SAGE.

Dooren, W.V., Caluwe, C.D., Lonti, Z. (2012). How to Measure Public Administration Performance: A Conceptual Model with Applications for Budgeting, Human Resources Management, and Open Government. Public Performance \& Management Review, 35(3), pp. 489-508

Dooren, W.V., Bouckaert, G., Halligan, J. (2015). Performance Management in the Public Sector. London: Routledge, https://doi.org/10.4324/9781315817 590

Goh, S. C. (2012). Making Performance Measurement Systems More 
Jurnal Administrasi Negara

ISSN : 2598-4039 (Online)

ISSN : 2302-2221 (Print)
Eny Diana Mudrikah, Roy V. Salomo

Program Magister Ilmu Administrasi

Fakultas Ilmu Administrasi

Universitas Indonesia
Effective in Public Sector

Organizations. Measuring Business

Excellence, 16(1),

31-42.

doi:http://dx.doi.org/

10.1108/13683041211204653

Halachmi, A. \& Holzer, M. (2010).

Citizen Participation and

Performance Measurement:

Operationalizing Democracy

Through Better Accountability. PAQ, (Fall):378-399.

Ho, A. T. (2007). Citizen Participation in Performance Measurement. In R. Box (Ed.), Democracy and Public Administration (pp. 107-118). Armonk, NY: M.E. Sharp

Ho, A.T.K. (2008). Reporting Public Performance Information: The Promise and Challenges of Citizen Involvement. In: Van Dooren W., Van de Walle S. (eds) Performance Information in the Public Sector. Governance and Public Management Series. Palgrave Macmillan, London. https://doi.org/10.1007/ 978-1 -13710541-7_13

Hunter, D. J., Kieslich, K., Littlejohns, P., Staniszewska, S., Tumilty, E., Weale, A., \& Williams, I. (2016). Public involvement in health priority setting: Future Challenges for Policy, Research and Society. Journal of Health Organization and Management, 30(5), 796-808. doi:http://dx.doi.org/10.1108/JHO M-04-2016-0057
Ianniello, M., Iacuzzi, S., Fedele, P., \& Brusati, L. (2019). Obstacles and Solutions on the Ladder of Citizen Participation: A Systematic Review. Public Management Review, 21(1), 21-46.

doi:10.1080/14719037.2018.1438499

Kementerian

Perencanaan

Pembangunan Nasional/Bappenas. (2017). Evaluasi Paruh Waktu RPJMN 2015-2019. Jakarta: Bappenas

Kementerian

Perencanaan Pembangunan Nasional/Bappenas. (2019). Kajian Sektor Kesehatan: Pengawasan Obat dan Makanan, termasuk Keamanan Pangan. Jakarta: Direktorat Kesehatan dan Gizi Masyarakat-Kedeputian Pembangunan Manusia, Masyarakat, dan KebudayaanKementerian PPN/Bappenas.

Kempeneer, S., Van Dooren, W. (2019). Using Numbers That Do Not Count: How the Latent Functions of Performance Indicators Explain Their Success. International Review of Administrative Sciences, 0(0), 116. doi:10.1177/00208523198 57804

Kushadajani, Permana. (2020). Inovasi Pemberdayaan Masyarakat Desa: Peran Kepemimpinan Lokal dalam Perspektif Relasi Antar Aktor. JIIP: Jurnal Ilmiah Ilmu Pemerintahan, 5(1), pp. 70-80, https://doi.org/10.14710/jiip.v5i1.73 18 
Jurnal Administrasi Negara

ISSN : 2598-4039 (Online)

ISSN : 2302-2221 (Print)
Eny Diana Mudrikah, Roy V. Salomo

Program Magister Ilmu Administrasi

Fakultas Ilmu Administrasi

Universitas Indonesia
Loeffler, E, Martin, S. (2016). Citizen Engagement, in T. Bovaird \& E. Loeffler. Public Management and Governance. London: Routledge, https://doi.org/10.4324/9781315693 279. pp 522-548.

Markic, D.(2014). A Review on the Use of Performance Indicators in the Public Sector. TEM Journal, 3(1), 2228.

Matsuda, N. (2009). Citizens in the Era of Governance: Citizen Participation and Active Citizenship. Interdisciplinary Information Sciences. 15(2). 231-242.DOI 10.4036/iis.2009. 231

Mpinga, E. K., Chastonay, P. (2011). Satisfaction of Patients: a Right to Health Indicator?. Health Policy (Amsterdam, Netherlands), 100(23), 144-150. https://doi.org/10.1016/j.healthpol. 2010.11.001

Nabatchi, T., \& Leighninger, M. (2015). Public Participation For 21st Century Democracy. Hoboken: John Wiley \& Sons, Incorporated.

Patton, M. Q. (2014). Qualitative Research \& Evaluation Methods Integrating Theory and Practice 2019.1569503
(Fourth Edition). Thousand Oaks, California: Sage Publications.

Parmenter, D. (2020). Key Performance Indicators: Developing, Implementing, and Using Winning KPIs, Fourth Edition. Hoboken, NJ: Wiley. DOI:10.1002/9781119620785

Poister, T. H., Aristigueta, M. P., \& Hall, J. L. (2015). Managing and Measuring Performance in Public and Nonprofit Organizations: An Integrated Approach (Second ed.). Somerset: John Wiley \& Sons, Incorporated.

Suebvises, P. (2018). Social Capital, Citizen Participation in Public Administration, and Public Sector Performance in Thailand. World Development, 109, 236-248. doi:10.1016/j.worlddev.2018.05.007

Uittenbroek, C. J., Mees, H. L. P., Hegger, D. L. T., \& Driessen, P. P. J. (2019). The Design of Public Participation: Who Participates, When and How? Insights in Climate Adaptation Planning from the Netherlands. Journal of Environmental Planning and Management, 62(14), 25292547. doi:10.1080/09640568. 